\title{
Anti-tumor potential of total alkaloid extract of Prosopis juliflora DC. leaves against Molt-4 cells in vitro
}

\author{
Mani Sathiya and Krishnaswamy Muthuchelian*
}

\author{
Department of Bioenergy, School of Energy, Environment and Natural Resources, Madurai Kamaraj University, Madurai \\ - 625 021, India.
}

Accepted 13 January, 2011

\begin{abstract}
The total alkaloid extract from Prosopis juliflora DC. leaves was obtained using acid/base modified extraction method. The in vitro anti-tumor potential of the extract was evaluated using MTT (3-(4,5dimethythiazol-2yl)2,5-diphenyl tetrazolium bromide) based cytotoxicity monitoring after 24,48 and $72 \mathrm{~h}$ exposure of the MOLT-4 cells $\left(1 \times 10^{6} \mathrm{cells} / \mathrm{ml}\right.$ medium) to different concentration of the extract ranging from 10 to $100 \mu \mathrm{g} / \mathrm{ml}$ medium. The genotoxic potential of the extract was also tested using cytokinesis block in vitro micronucleus assay. Simultaneously, the cytotoxic and genotoxic potential of the extract were compared with mitogen stimulated T-lymphocyte cultures derived from peripheral blood of healthy volunteers. The MTT test revealed that, the extract exhibited comparatively higher toxicity towards the cancer cells than the normal cells at all the tested concentrations and at all the time points studied. The $\mathrm{IC}_{50}$ values of the extract at 24,48 and $72 \mathrm{~h}$ were found to be $90.5,42.5$ and $20.0 \mu \mathrm{g} / \mathrm{ml} / 1 \times 10^{6}$ cells against cancer cells. The genotoxic assay showed that, in both cultures, the number of micronuclei obtained even at the highest exposure concentration tested was very low when compared with that of the micronuclei obtained with the positive control mitomycin-C. The results of the present investigation demonstrate that, $\boldsymbol{P}$. juliflora leaf alkaloids are preferentially cytotoxic to human T-cell leukemia (Molt-4) cells in a dose and time dependent manner with the absence of genotoxicity.
\end{abstract}

Key words: Prospis juliflora, alkaloids, molt-4 cells, MTT test, micronucleus assay.

\section{INTRODUCTION}

Cancer is the second leading cause of death in the world (Madhusudan and Middleton, 2005). Currently over $60 \%$ of the drugs are derived in one or the other way from natural sources including plant, marine organisms and micro-organisms (Newman et al., 2003). Among many recent advances in cancer chemotherapy, plant natural products have played an important role in contributing to approximately 60 cancer chemotherapeutic drugs on the market including Catharanthus (Vinca) alkaloids (vinblastine, vincristine, vinorelbine), the pipodophyllotoxins

*Corresponding author. E-mail: drchelian1960@yahoo.co.in. Tel: +91 452 2458020. Fax: +91 452-2459181.

Abbreviations: RPMI, Roswell Park Memorial Institute medium; MTT, 3-(4,5-dimethythiazol-2yl)2,5-diphenyl tetrazolium bromide; BNC, binucleated cells; $\mathbf{I C}_{50}$, concentration of the extract required for $50 \%$ of reduction in cell proliferation. (etoposide, etoposide phosphate, teniposide), the taxanes (paclitaxel and docetaxel) and the camptothecin derivatives (irinotecan and topotecan) (Cragg et al., 1997; Kinghorn, 2000; Conforti et al., 2008; Dholwani et al., 2008; Bhuvan et al., 2009). Recently, there is considerable scientific and commercial interest in the continuing discovery of new anticancer agents from plant products (Kinghorn et al., 2003; Cragg and Newman, 2005) and such investigations about plant products have recently regained prominence with the increasing understanding of their biological significance and increasing recognition of the origin and function of their structural diversity (Conforti et al., 2008). In large number of medicinal plants, the therapeutic value is due to the presence of alkaloids, which in certain respects, ranks among the most interesting of the naturally occurring substances (Ahmad et al., 1995).

Prosopis juliflora DC., mesquite tree is one of the major invasive alien species of India and it has been used to treat eye problems, open wounds, dermatological ailments 
and digestive problems by the native tribes of many countries (Kirtikar and Basu, 1935; Davidow, 1999). It has soothing, astringent, antiseptic, antibacterial and antifungal properties (Ahmad et al., 1995; Kay, 1996). The extracts of $P$. juliflora seeds and leaves were well studied for several in vitro pharmacological effects such as antibacterial (Aqeel et al., 1989; Kanthasamy et al., 1989; Caceres et al., 1995; Satish et al., 1999), antifungal (Ahmad et al., 1989a,b; Kaushik et al., 2002) and anti-inflammatory properties (Ahmad et al., 1989a,b). These properties have been attributed to piperidine alkaloids (Ahmad et al., 1986; Batatinha, 1997). The main alkaloids including the juliflorine and julifloricine of $P$. juliflora were isolated by Ahmad et al. (1978) and their antibacterial and antifungal activities have also been reported (Khan et al., 1986; Ragavendra et al., 2009). The flavonoid patulitrin isolated from its flowers and fruits showed significant activity against lung carcinoma in vivo (Wassel et al., 1972).

To the best of our knowledge, the effect of $P$. juliflora alkaloids on human cancer cell lines in vitro or in vivo has hitherto not been reported. A successful anticancer drug should kill or incapacitate cancer cells without causing excessive damage to normal cells (Sharma et al., 2009). With this background, the present research is thus, motivated by the need to find new substances of natural origin which possess anti-tumor activities with a low degree of toxicity for humans and an attempt has been made to screen the cytotoxic effect of the total alkaloid extract from its leaves against the T-cell leukemia (Molt4) cells as well as on mitogen stimulated T-lymphocyte cultures derived from the venous blood of healthy volunteers in vitro using the standard 3-(4,5dimethythiazol-2yl)2,5-diphenyl tetrazolium bromide (MTT) test. Simultaneously, the extracts were subjected to genotoxic assessment using cytokines block in vitro micronucleus assay on cancer and normal cells to evaluate their safety.

\section{MATERIALS AND METHODS}

\section{Chemicals and reagents}

All reagents and solvents used in the study were of analytical grade. Histopaque 1077, L-glutamine, mitomycin-C and cytochalasin-B were purchased from Sigma, St Louis, USA. RPMI1640 medium, MTT, streptomycin and penicillin were purchased from Himedia, Mumbai, India. Phytohemeagglutinin and fetal calf serum were obtained from Gibco, New York, USA. All the other chemicals were purchased from SD Fine Chemicals, Mumbai, India.

\section{Collection of leaves and extraction of alkaloids}

Leaves of $P$. juliflora were harvested from the Centre for Biodiversity and Forest Studies of Madurai Kamaraj University. The total alkaloids were extracted by the method of Ott-Longoni et al. (1980) with slight modifications (Kandasamy et al., 1989). The leaves were dried, powdered and defated by cold hexane extraction. The defated powder was subjected to repeated methanol extraction and the combined extracts were concentrated in vacuum. The concentrated residue was stirred with $0.2 \mathrm{~N} \mathrm{HCl}$ and filtered after $16 \mathrm{~h}$. The aqueous solution was shaken with methylene chloride to remove the non basic material and they were made alkaline with ammonium hydroxide in cold. The alkaline solution was extracted with methylene chloride and the organic extract was passed though anhydrous sodium sulphate. The resulting solution was evaporated to dryness to yield total alkaloids of $P$. juliflora. The alkaloids freed from other components like flavonoids, glycosides and saponins were tested for their purity using their respective identification test by adopting the method of Peach and Tracey (1959).

\section{Cells, media and culture conditions}

Human T-cell leukemia (Molt-4) cells procured from National Centre for Cell Sciences, Pune, India were used for evaluating anticancer potential. Mitogen stimulated T-lymphocyte cultures derived from venous blood of healthy persons were used for normal cells. Both cells were maintained in Roswell Park Memorial Institute medium (RPMI)-1640 media supplemented with $10 \%$ heat inactivated fetal calf serum, $2 \mathrm{mM}$ L-glutamine, $0.4 \%$ sodium bicarbonate, $100 \mathrm{U} / \mathrm{ml}$ penicillin, $100 \mu \mathrm{g} / \mathrm{ml}$ streptomycin and $2 \%$ phytohemeagglutinin in a humidified atmosphere containing $5 \% \mathrm{CO}_{2}$.

Peripheral whole blood (15 ml) from 3 healthy, 22 to 25 years old female volunteers was collected with informed consent in heparinized vacutainer tubes (Becton Dickinson Lab ware, USA). Donors were nonsmokers and had not been exposed to chemicals, drugs or $\mathrm{x}$ rays in the last 6 months before blood sampling. Lymphocytes were separated using histopaque-1077 (a leukocyte separation technique by Sigma Diagnostics) by density gradient centrifugation at $500 \mathrm{~g}$ for $10 \mathrm{~min}$. After recovering the buffy coat, lymphocytes were washed twice with phosphate buffered saline and resuspended in complete media. Lymphocytes were counted using heamocytometer and adjusted to a density of $1 \times 10^{6}$ cells $/ \mathrm{ml}$ for cell culture studies.

\section{Determination of cell viability and selection of exposure concentration}

The extracts were dissolved in $100 \mu \mathrm{l}$ of phosphate buffered saline and diluted with RPMI-1640 medium to obtain 1, 2, 5, 10, 20, 50, $100,200,500$ and $1000 \mu \mathrm{g} / \mathrm{ml}$ medium for cell viability assay. Lymphocytes were isolated from the venous blood of healthy volunteers using lymphocyte separation medium and about $1 \times 10^{6}$ cells were seeded in 96 well plates. $150 \mu \mathrm{l}$ of culture medium containing different concentrations of extract was added to each well and incubated for $24 \mathrm{~h}$ at $37^{\circ} \mathrm{C}$ in an atmosphere of $5 \% \mathrm{CO}_{2}$. After $24 \mathrm{~h}$ incubation, $50 \mu \mathrm{l}$ of $0.4 \%$ erythrosine-B in phosphate buffered saline was added to each well and again incubated for 30 min. The number of stained (dead) and unstained (live) cells were counted using hemocytometer under the microscope. From that, the cell viability was calculated for each concentration. Experimental dosages which resulted in viability of $70 \%$ and above were decided as optimum for cell culture studies.

\section{Screening of anticancer potential using MTT test}

The cytotoxic potential of $P$. juliflora leaf alkaloids against cancer cells was tested using MTT assay which is based on the respiratory ability of the mitochondrial succinate-tetrazolium reductase system, which converts the yellow tetrazolium salt to a purple formazan dye. The amount of formazan produced by the dehydrogenase enzymes was directly proportional to the number of living cells in culture. About $1 \times 10^{6}$ cancer (Molt-4) and normal (lymphocytes from healthy 
donors) cells were seeded in 96 well plates, treated with 10, 20, 50 and $100 \mu \mathrm{g}$ of $\mathrm{TAE} / \mathrm{ml}$ medium and incubated at $37^{\circ} \mathrm{C}$ in an atmosphere of $5 \% \mathrm{CO}_{2}$ for 24,48 and $72 \mathrm{~h}$. Cells incubated in complete medium without TAE served as control. At the end of incubation, medium was removed and $50 \mu \mathrm{l}$ MTT $(5 \mathrm{mg} / \mathrm{ml})$ was added and the cells were further incubated for $4 \mathrm{~h}$. After the incubation, the MTT solution covering the cells was removed. 100 $\mu \mathrm{l}$ of dimethyl sulphoxide was added to the wells and the cell viability was determined by measuring the absorbance in a micro plate reader with a test wave length of $570 \mathrm{~nm}$ and a reference wave length of $630 \mathrm{~nm}$ (Mosmann, 1983). The experiment was repeated thrice. Cell viability was calculated using the following formula and from that the percentage of cytotoxicity and $\mathrm{IC}_{50}$ values of leaf extracts were calculated for the different time points studied.

$\%$ of cell viability $=($ Mean OD of experimental wells/Mean OD of control wells) $\times 100$.

\section{Genotoxic assessment using cytokinesis-block micronucleus assay}

The micronucleus assay was performed according to Matsuoka et al. (1992) with modifications (Bonacker et al., 2004). About $1 \times 10^{6}$ cells $/ \mathrm{ml}$ medium were exposed to increasing concentrations of leaf extracts in $5 \mathrm{ml}$ culture medium and incubated at $37^{\circ} \mathrm{C}$ in an atmosphere of $5 \% \quad \mathrm{CO}_{2}$. Mitomycin-C $(6 \mu \mathrm{gg} / \mathrm{ml}$ medium $)$ and complete media were treated as positive and negative controls, respectively. After $44 \mathrm{~h}$, cytochalasin-B $(6 \mu \mathrm{g} / \mathrm{ml})$ was added and further incubated for $28 \mathrm{~h}$. At the end of incubation, the cells were harvested by low centrifugation, treated with a hypotonic solution of $\mathrm{KCl}(0.075 \mathrm{M})$ and fixed in methanol acetic acid (3:1) for 3 to $4 \mathrm{~h}$. Two to three drops of the fixed cell suspension were dispensed onto the surface of cold microslides, air dried and stained with $3 \%$ Giemsa solution in Sorenson phosphate buffer $(\mathrm{pH} \mathrm{6.8)}$ for 5 to 7 min. The slides were coded and for each treatment, at least 2000 binucleated cells (BNC) per concentration were scored blind for micronucleus frequency in each treatment. The criteria employed for the analysis of micronuclei and binucleated cells, were established by Fenech (2000).

\section{Statistical analysis}

All the experiments were independently preformed thrice with three replicates for each treatment. The results were expressed as mean \pm SEM. and were analyzed by one-way analysis of variance (ANOVA) followed by Tukey test and $p<0.05$ was considered statistically significant.

\section{RESULTS}

The results of cell viability assay based on the erythrosine $B$ dye exclusion potential of living cells treated with logarithmically increasing concentration of TAE of $P$. juliflora are presented in Figure 1 . It is very much clear that the optimum viability (70 and above) lies within $100 \mu \mathrm{g}$ level for all the extract which provided a way to determine the concentration range suitable for cell culture studies.

The anticancer potential of TAE was tested by MTT assay and the results are presented in Figure 2. From the results, it can be observed that, the extract exhibited significantly higher cytotoxicity on cancer cells than in normal cells by exhibiting $I_{50}$ values of $90.5 \pm 2.5,42.5 \pm$ 1.75 and $20 \pm 0.5 \mu \mathrm{g}$ after 24,48 and $72 \mathrm{~h}$ exposure durations, for cancer cells (Table 1). When the same extracts were exposed to normal cells for the same duration at similar concentration, determination of $\mathrm{IC}_{50}$ values to normal cells was not possible at all the time points studied which showed that, the growth inhibition by TAE was significantly lesser in normal cells than in cancer cells.

The percentage of cytotoxicity increased with increasing concentration as well as exposure duration. The cytotoxicity observed in cancer cells at the highest exposure concentration ( $100 \mu \mathrm{g} / \mathrm{ml}$ medium) was found to be $53.86,66.74$ and $72.65 \%$ after 24,48 and $72 \mathrm{~h}$ incubition, where as, the same for normal cells was found to be $29.24,38.37$ and $46.51 \%$, respectively for the same durations. Similarly, the cytotoxicity observed in cancer cells at the lowest exposure concentration was found to be $53.86,36.55$ and $46.71 \%$ after 24,48 and $72 \mathrm{~h}$ incubition, where as, the same for normal cells was found to be $8.31,11.27$ and $18.43 \%$, respectively, at the same durations.

The cytokinesis-block in vitro micronucleus test provides a very accurate and efficient tool to detect chromosomal aberrations as micronuclei in divided verses non-divided cells. The results of micronucleus assay have been presented in Figure 3. As a measure of cell proliferation, the number binucleated cells obtained in each treatment was counted. BNC yield was inversely proportional to the concentration of extract in both cultures and was expressed as percentage. In both cells, maximum BNC was observed in the positive control. The BNC observed in cancer cells were of $68.22,53.35$, $47.59,43.83,37.74$ and $32.17 \%$ for the negative control; $10,20,50,100 \mu \mathrm{g}$ TAE for the positive control, respectively. The BNC observed in normal cells were of $76.48,67.35$, $62.16,59.26,54.37$ and $52.47 \%$ for the negative control, and $10,20,50,100 \mu \mathrm{g}$ TAE for positive control, respectively. Like wise the total number of micronuclei counted in cancer cells were of $9.4,16.6,19.33,22.48,25.65$ and $52.52 \%$ for the negative control, 10, 20, 50, $100 \mu \mathrm{g} \mathrm{TAE}$ for positive control, respectively. Where as, the total number of micronuclei counted in normal cells were of $6.5,15.78,16.86,20.46,23.75$ and $48.79 \%$ for the negative control, 10, 20, 50, $100 \mu \mathrm{g}$ TAE for positive control, respectively. The number of micronuclei obtained, showed a gradually increasing pattern with increasing concentration of the extract in both cultures. But, the micronuclei obtained even at the maximum concentration were significantly lower than that of the positive control. In both cultures, there was no significant difference between the number of micronuclei observed in lowest concentration tested and the negative control, indicating the possible absence of genotoxicity at this concentration.

\section{DISCUSSION}

Cultures of cancer (Molt-4) and normal (T lymphocytes 
Table 1. $\mathrm{IC}_{50}$ values of total alkaloid extract of $P$. juliflora leaves against the human leukemia cells (Molt-4) after 24, 48 and $72 \mathrm{~h}$ incubation periods as determined from the results of MTT based cytotoxicity test.

\begin{tabular}{ll}
\hline $\begin{array}{l}\text { Exposure } \\
\text { duration }(h)\end{array}$ & $\begin{array}{l}\mathrm{IC}_{50} \text { values of TAE }\left(\mu \mathrm{g} / \mathbf{1} \times 10^{6} \mathrm{cells} / \mathrm{ml}\right. \\
\text { medium) }\end{array}$ \\
\hline 24 & $90.5 \pm 2.5$ \\
48 & $42.5 \pm 1.75$ \\
72 & $20 \pm 0.5$ \\
\hline
\end{tabular}

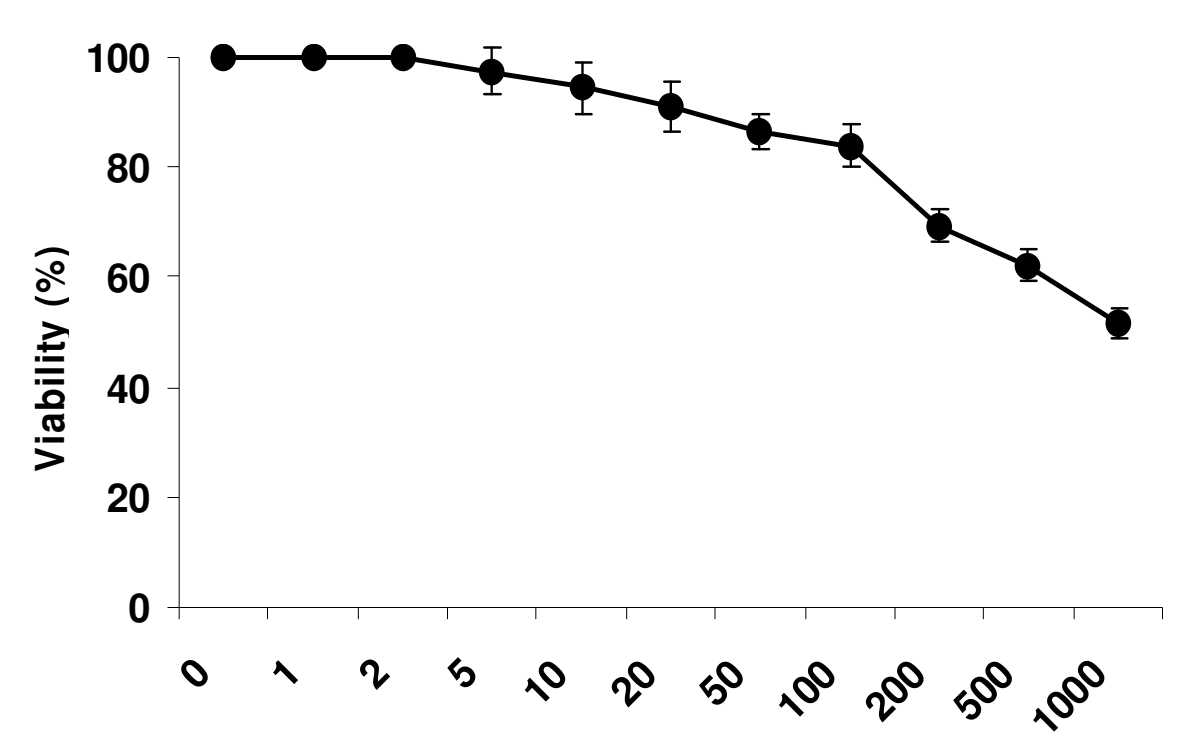

Concentration of TAE of $P$. juliflora leaves (ug/ml)

Figure 1. Viability of normal lymphocytes exposed to increasingly logarithmic concentration of total alkaloid extract of $P$. juliflora leaves.

from healthy volunteers) cells were exposed to different concentrations of TAE isolated from $P$. juliflora leaves such as $10,20,50,100 \mu \mathrm{g} / 1 \times 10^{6} \mathrm{cells} / \mathrm{ml}$ medium, to study the effect on cell proliferation. As determined by MTT assay, the maximum cytotoxicity observed with cancer and normal cells were found to be 72.65 and $46.51 \%$ at the highest dosage and longest exposure duration studied and the minimal observations were about 21.71 and $8.31 \%$ on cancer and normal cells, respectively, at the lowest dosage and exposure duration tested. The cleavage of tetrazolium ring in MTT involves the mictochondrial succinate dehydrogenase and depends on the activity of the respiratory chain and the redox state of the mitochondria (Mosman, 1983; Shearman et al., 1995) responsible for the production of cell energy. The exposure of cancer cells to TAE induced a significant reduction in the conversation of MTT, which means a cellular disintegration and cytotoxicity reflected from the parallel dose and time dependent decrease of the absorbance measured.

Several plant extracts and their isolated compounds have been shown to possess antioxidant, antiinflammatory and anti-tumor properties (D' Alessandro et al., 2003; Kim and Lee, 2004; Arts and Hollman, 2005; Lambert et al., 2005). The scientific evaluation of traditional medicinal plants would assure the credibility of their uses (Garcia-Alvarado et al., 2001; Gomez-Flores et al., 2009) and this has led to the discoveries of many important drugs and their secondary metabolites and has also show promises for the cancer chemoprevention, which has been defined as "the use of non-cytotoxic nutrients or pharmacological agents to enhance physiological mechanisms that protect the organism against mutant clones of malignant cells" (Morse and Stoner, 1993).

Recently, several plant extracts have been evaluated and shown to have cytotoxic or cytostatic effects in cancer cell lines. They include those of Solanum lyratum tested on human colon adenocarcinoma cell line (colo 205) (Hsu et al., 2008), Annona glabra on human leukemia cell lines (CEM/VLB) (Cochrane et al., 2008), Gynostemma pentaphyllum on human lung cancer (A549) 

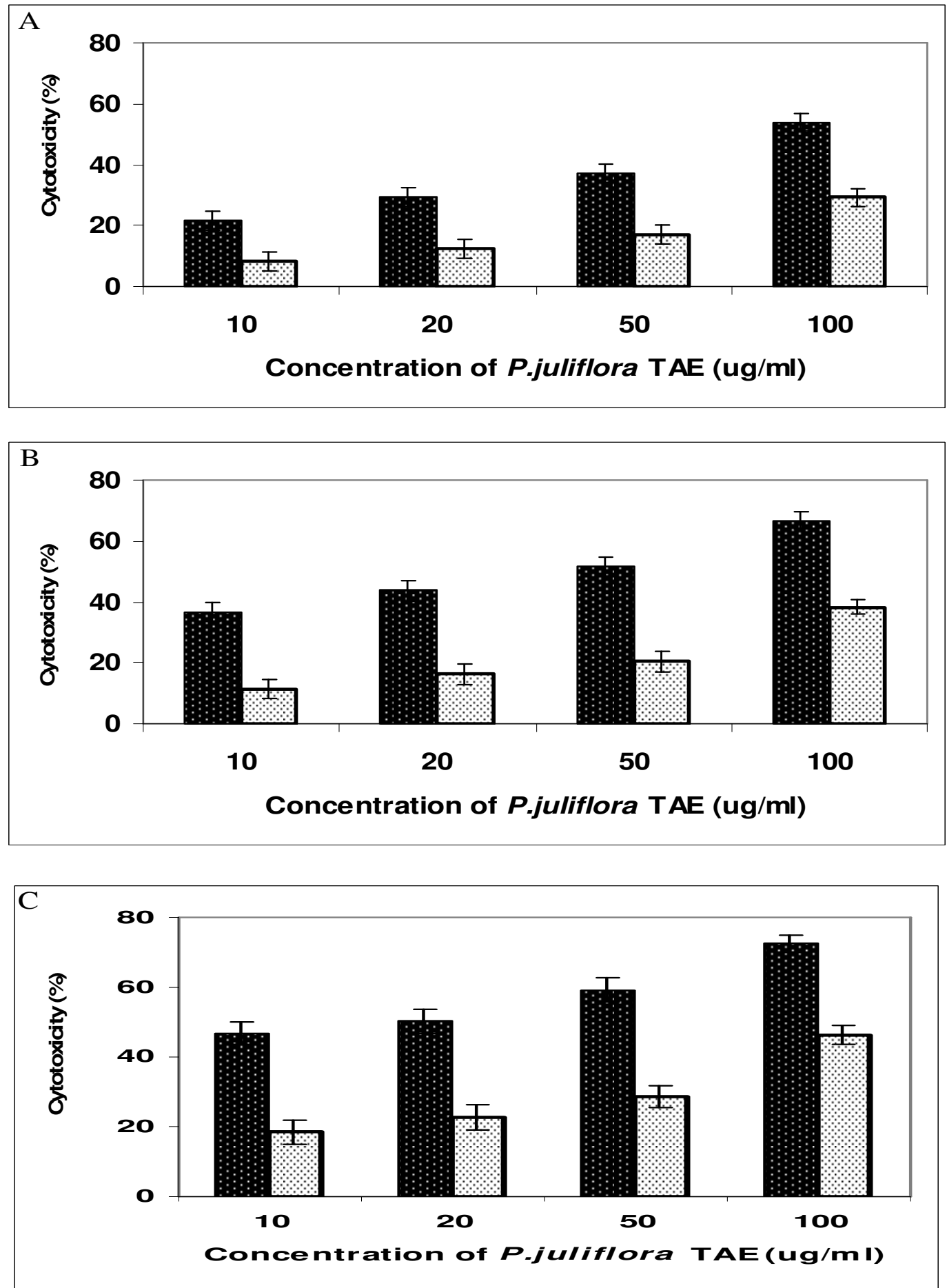

Figure 2. Cytotoxic effect of total alkaloid extract of $P$. juliflora leaves against cancer (black bars) (Molt-4 cells) and normal (white bars) (mitogen stimulated T-lymphocytes from the venous blood of healthy volunteers) cells after 24 (A), 48 (B) and (c) $72 \mathrm{~h}$ incubation period. Each determination was performed from three replicates of three independent experiments.

(Lu et al., 2008), Blumea balsamifera on rat and human hepatocellular carcinoma cells (McA-RH7777 and HepG2) (Norikura et al., 2008) and Artocarpus altilis on human breast cancer (T47D) cells (Arung et al., 2009).
It is important to determine the potential genetic hazards of compounds present in medicinal plants aligned with their beneficial effects to the human body and the verification of the possible mutagenic and/or anti- 


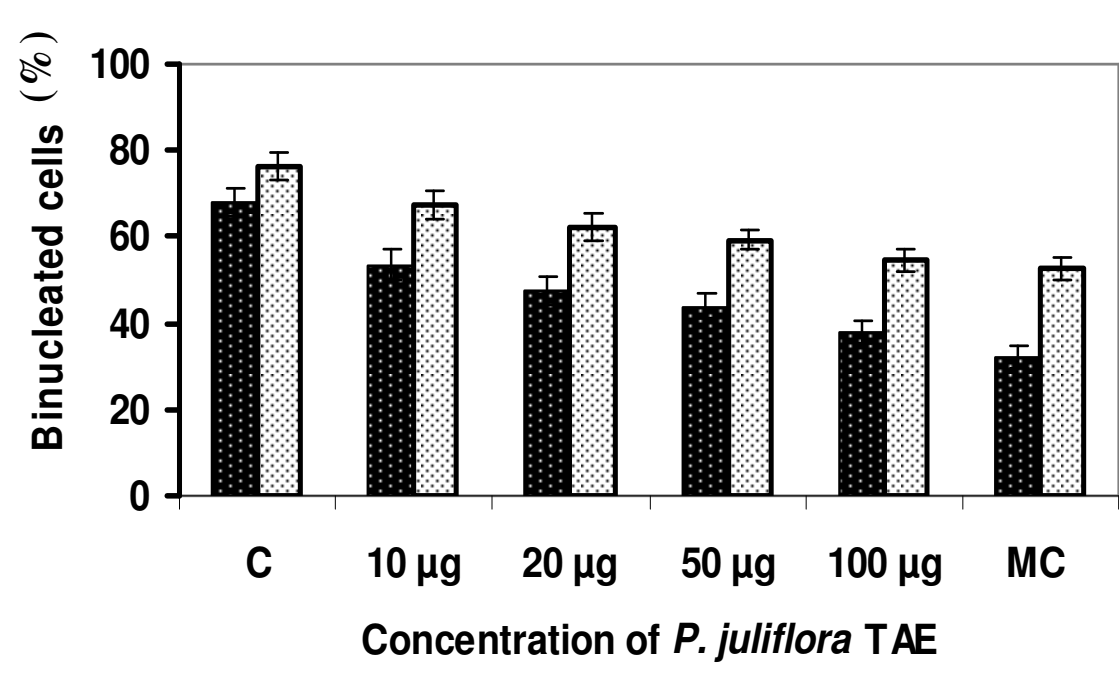

A

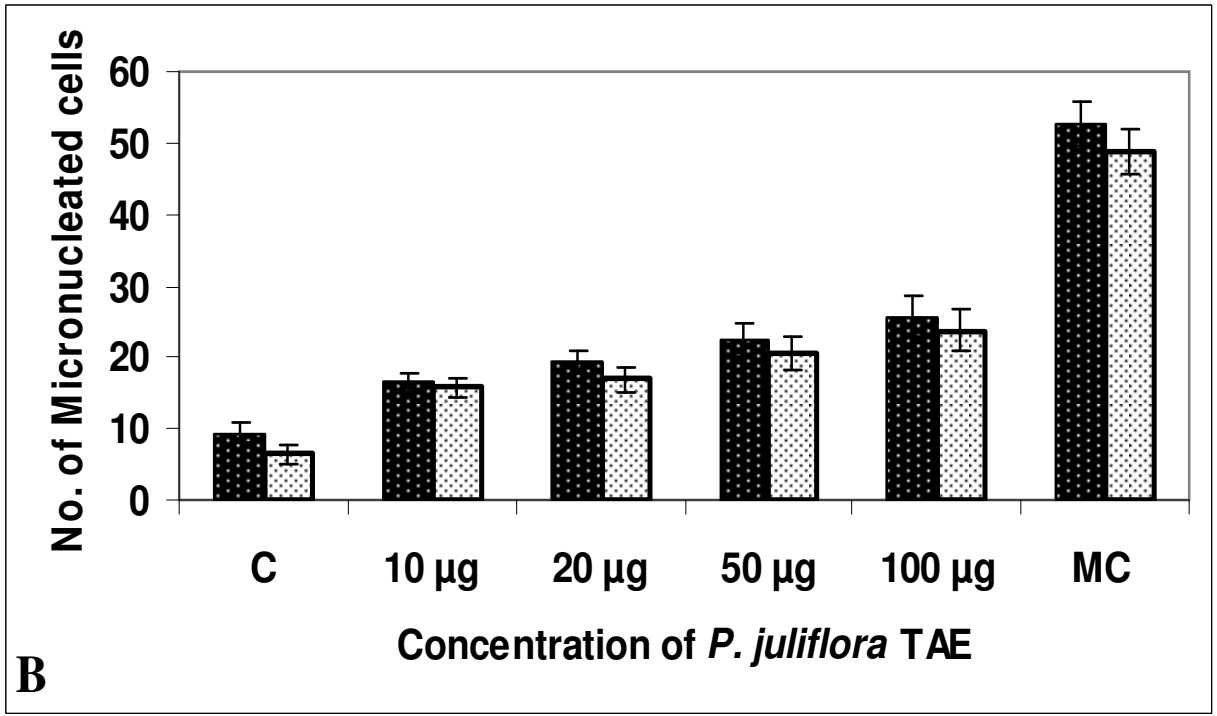

Figure 3. Genotoxic evaluation of total alkaloid extract of $P$. juliflora leaves against cancer (black bars) and normal (white bars) cells as measured by cytokines block in vitro micronucleus assay. Each determination was performed from three replicates of three independent.

mutagenic effects of medicinal plants infusion/extracts is another important factor in scientific evaluation studies. Such effects have been elucidated in some plant species using various test systems (Roncada et al., 2004). However, biological data on the medicinal properties associated with plant extracts with phytopharmacological activities are relatively few, especially regarding mutagenic potential (Lohman et al., 2001).

Hence, the biological activity of the alkaloid extract was measured in order to test the possible clestogenic or aneugenic effect through the induction of micronuclei which reflects its genotoxic potential. There is a vast difference between the number of micronuclei observed in cultures exposed to TAE and the positive control that is, mitomycin-C. The maximum number of micronuclei induced by TAE at the highest tested concentration was found to be 25.65 and 23.75 for cancer and normal cells, respectively and it was 52.52 and 48.79 by the mitomycin-C. This two fold rise in the number of micronuclei formed by mitomycin-C attributed with the highly significant difference between the values. The results of the cytokinesis block in vitro micronucleus assay revealed the lack of genotoxic potential in these cells which are corroborative with the previous findings of mutagenicity study through Ames test using some of the alkaloids from this plant that proved their non- mutagenicity up to $500 \mathrm{\mu g} /$ 
plate (Ahmad et al., 1991).

From the results of MTT test and micronucleus assay, it has been observed that the extract has significantly higher anti-proliferative effect on cancer cells than that of the normal cells in a dose and time dependent manner, and the number of micronuclei formed even at the highest concentration tested was insignificant with that of the positive control thus indicating the possibility of the lack of genotoxicity associated with its anti-tumor potential.

Taking together the stated results, it is clear that the TAE of this plant have anti proliferative potential against the Molt-4 cells in vitro. Although the TAE has shown some encouraging results, they need to undergo careful controlled trials in order to evaluate their usefulness and safety against wide range of cancer and normal cell lines, and elaborate studies are required to determine intracellular pathway(s) involved in the mechanism of cytotoxicity. Further studies on this plant with its pure compounds may lead to the development of newer and safer anticancer drugs with higher therapeutic potential. Hence, this can open a new avenue for the effective management of this menace invasive alien species in a useful manner.

\section{ACKNOWLEDGEMENTS}

The authors thank the University Grants Commission of India for the grant of UPE (University with Potential for Excellence) project and Dr. K. K. Natarajan, Head, Department of Botany, Saraswathi Narayanan College, Madurai - 625021 , India, for the necessary corrections performed during the manuscript preparation.

\section{REFERENCES}

Ahmad A, Ahmad V, Khalid SM, Siddiqui SA, Khan KA (1995). Study of the antibacterial therapeutic efficacy of juliflorine, julifloricine and a benzene insoluble alkaloidal fraction of Prosopis juliflora. J. Islamic Acad. Sci. 8(3): 131-136.

Ahmad A, Khan KA, Ahmad VU (1991). Toxicological studies of antimicrobial alkaloid juliflorine. Arzneim-Forsch/Drug Res. 41(1):151154, 1991.

Ahmad A, Khan KA, Ahmad VU, Quazi S (1986). Antibacterial activity of juliflorine isolated from Prosopis juliflora. Planta Med. 1(1): 285-288.

Ahmad A, Khursheed AK, Sabiha Q, Viqaruddin A (1989a). Antifungal activity of some hydrosoluble Prosopis juliflora alkaloids. Fitoterapia. 60(1): 86-89.

Ahmad VU, Sultana A, Qazi S (1989b). Alkaloids from the leaves of Prosopis juliflora. J. Nat. Prod. 52(3): 497-501.

Ahmad VU, Basha A, Haque W (1978). New alkaloids from Prosopis juliflora DC. Z. Naturforsch. 33:347-348.

Aqeel A, Khursheed AK, Viquaruddin A, Sabiha Q (1989). Antibacterial activity of julifloricine isolated from Prosopis juliflora. ArzneimForesch./Drug Res., 39(6): 652-655.

Arts IC, Hollman PC (2005). Polyphenols and disease risk in epidemiologic studies. Am. J. Clin. Nutr. 81: 317S-325S.

Arung ET, Wicaksono BD, Handoko YA, Kusuma IW, Yulia D, Sandra F (2009). Anti-cancer properties of diethylether extract of wood from sukun (Artocarpus altilis) in human breast cancer (T47D) cells. Trop. J. Pharm. Res. 8 (4): 317-324.
Batatinha MJM (1997). Untersuchungen uber toxische einflusse von Prospis juliflora Sw.D.C (Algarobeira)auf Zellkulturen sowie auf die pansenfermentation beim rind (in vitro) [Doctoral thesis]. Hannover: Veterinary Medicine University.

Bhuvan RP, Jignesh PD, Bhavik PA, Ashok GL (2009). Potent in vitro anticancer activity of Symplocos racemosa bark. Rom. J. Biol. - Plant Biol. 54(2): 135-140.

Bonacker D, Stoiber T, Wang M, Bohm KJ, Prots I, Unger E, Their R, Bolt HM, Degen, GH (2004). Genotoxicity of inorganic mercury salts based on disturbed microtubule function. Arch. Toxicol. 78: 575-583.

Cochrane CB, Nair PK, Melnick SJ, Resek AP, Ramachandran C (2008). Anticancer effects of Annona glabra plant extracts in human leukemia cell lines. Anticancer Res. 28: 965-971.

Conforti F, loele G, Statti GA, Marrelli M, Ragno G, Menichini F (2008). Antiproliferative activity against human tumor cell lines and toxicity test on mediterranean dietary plants. Food and Chem. Toxicol. 46: 3325-3332.

Cragg GM, Newman DJ (2005). Plants as a source of anti-cancer agents. J. Ethnopharmacol. 100: 72-79.

Cragg GM, Newman DJ, Weiss RB (1997). Coral reefs, forests, and thermal vents: the worldwide exploration of nature for novel antitumor agents. Sem. Oncol. 24: p. 156.

D' Alessandro T, Prasain J, Benton MR, Botting N, Moore R, DarleyUsmar V, Patel R, Barnes S (2003). Polyphenols, inflammatory response, and cancer prevention: chlorination of isoflavones by human neutrophils. J. Nutr. 133: 3773S-77S.

Davidow J (1999). Infusions of Healing: A treasury of Mexican-American herbal remedies. Simon and Schuster Inc., p. 149.

Dholwani KK, Saluja AK, Gupta AR, Shah DR (2008). A review on plant derived natural products and their analogues with antitumor activity. Ind. J. Pharmacol. 40(2): 49-58.

Fenech M (2000). The in vitro micronucleus technique. Mutat. Res. 8195.

Garcia-Alvarado J, Verde-Star J, Heredia NL (2001). Traditional uses and scientific knowledge of medicinal plants from Mexico and Central America. J. Ethnopharmocol. 8: 37-89.

Gomez-Flores RH, Gracia-Vásquez Y, Alanís-Guzmán MG, TamezGuerra1, P, Tamez-Guerra1 R, García-Díaz C, Monreal-Cuevas E, Rodríguez-Padilla C (2009). In vitro antimicrobial activity and polyphenolics content of tender and mature Ebenopsis ebano seeds. Medicinal Plants. 1(1): 11-19.

Hsu SC, Lu, JH, Kuo CL, Yang JS, Lin MW, Chen GW, Su CC, Lu HF, Chung JG (2008). Crude extracts of Solanum lyratum induced cytotoxicity and apoptosis in a human colon adenocarcinoma cell line (Colo 205). Anticancer Res. 28: 1045-1054.

Kandasamy A, William S, Govindaamy S (1989). Hemolytic effect of Prosopis juliflora alkaloids. Current Sci. 58(3): 142-143.

Kaushik JC, Sanjay A, Tripathi NN (2002). Antifungal properties of some plant extracts against the damping-off fungi of forest nurseries. Indian J. For. 25(3\&4): 359-361.

Kay MA (1996). Healing with plants in the American and Mexican West. Tuscon: The University of Arizona Press, 221-224.

Khan KA, Faruqi AH, Rasool SA, Ahmad VU Qazi S, Haroon TS (1986). Arzeim-Forsch/Drug Res. 36:17.

Kim DO, Lee CY (2004). Comprehensive study on vitamin C equivalent antioxidant capacity (VCEAC) of various polyphenolics in scavenging a free radical and its structural relationship. Crit. Rev. Food Sci. Nutr. 44: $253-273$

Kinghorn AD (2000). Plant secondary metabolites as potential anticancer agents and cancer chemopreventives. Molecules. 5: 285288.

Kinghorn AD, Farnsworth NR, Soejarto DD, Cordell GA., Swanson SM, Pezzuto JM,Wani MC, Wall ME, Kroll NH, Kramer RA, Rose WC, Vite GD, Fiarchild CR, Katalinic V, Milos M, Kulisic T, Jukic M (2003). Screening of 70 medicinal plant extracts for antioxidant capacity and total phenols. Food Chem. 94: 550-557.

Kirtikar KP, Basu BD (1935). Indian Medicinal Plants Vol II Leader Press Allahabad, 910.

Lambert JD, Hong J, Yang GY, Liao J, Yang CS (2005). Inhibition of carcinogenesis by polyphenols: evidence from laboratory investigations. Am. J. Clin. Nutr. 81: 284S-291S.

Lohman PHM, Gentile JM, Gentile G, Rueff T (2001). Antimutagenesis/ 
anticarcinogenesis: screening methods and biomarkers. Mutat. Res. 496: 1 -4.

Lu HF, Chen YS, Yang JS, Chen JC, Lu KW, Chiu TH, Liu KC, Yeh CC, Chen GW, Lin HJ, Chung JG (2008). Gypenosides induced G0/G1 arrest via inhibition of cyclin $E$ and induction of apoptosis via activation of caspases- 3 and -9 in human lung cancer A-549 cells. In Vitro. 22: 215- 221.

Madhusudan S, Middleton MR (2005). The immerging role of DNA repair proteins as predictive, prognostic, and therapeutics in cancer. Cancer Treat. Rev. 31: 603-617.

Morse MA, Stoner GD (1993). Cancer chemoprevention: principles and prospects. Carcinogenesis. 14, 1737-1746.

Mosmann T (1983). Rapid colorimetric assay for cellular growth and survival: application to proliferation and cytotoxicity assays. J. Immunol. Meth. 65: 55-63.

Newman DJ, Cragg GM, Snader, KM (2003). The natural products as a source of new drugs over the period 1981-2001. Jrnl. of Natl. Prdt. 66: 1022-1037.

Norikura T, Kojima-Yuasa A, Shimizu M, Huang X, Xu S, Kametani S, Rho SN, Kennedy DO, Matsui-Yuasa I (2008). Anticancer activities and mechanisms of Blumea balsamifera extract in hepatocellular carcinoma cells. Am. J. Chin. Med. 36: 411-24.

Ott-Longoni R, Viswanathan N, Hesse M (1980). Die constitution des alkaloids juliprosopin aus Prosopis juliflora DC. Helvet. Chim. Acta. 63(222): 2119-2129.
Peach K, Tracey MV (1959). Modern Method of Plant Analysis; Narosa Publishing House: New Delhi, 3: p. 64.

Ragavendra MP, Satish S, Raveesha KA (2009). Alkaloids isolated from leaves of Prosopis juliflora against Xanthomonas pathovars. Arch. of Phytopathol. Plant Protection. 42(11): 10331041.

Sharma PR, Mondhe DM, Muthiah S, Pal HC (2009). Anticancer activity of an essential oil from Cymbopogon flexuosus. Chemico-Biol. Interactions. 179:160-168.

Shearman MS, Hawtin SR, Tailor VJ (1995). The intra cellular component of cellular 3-(4,5-dimethythiazol-2yl)2,5-diphenyl tetrazolium bromide (MTT) reduction is specifically inhibited by $B$ amyloid peptites. J. Neurochem. 65:218-227.

Wassel GM, Rizk AM, Abdel-Bary EF (1972). Phytochemical investigation of Prosopis juliflora DC. Flavonoids and free sugars. Plant Foods for Hum. Nutri. 22(1):119-121. 